\title{
IMPLEMENTATION OF INTEGRATED NURSING MODELS TOWARD PATIENT SATISFACTION IN MITRA MEDIKA AMPLAS HOSPITAL, MEDAN, NORTH SUMATRA
}

\author{
Deli1,2), Destanul Aulia3), Heru Santosa3), Ida Yustina3) \\ 1)Postgraduate Program, Faculty of Public Health, Universitas Sumatera Utara, Medan \\ 2) Department of Faculty of Public Health, Institut Kesehatan Helvetia, Medan \\ 3)Departement of Public Health, Faculty of Public Health, Universitas Sumatera Utara
}

\begin{abstract}
Background: The patient's statement of the nurse's poor and needy performance reflects dissatisfaction. Communities need patient-focused services, and the success of nursing care is determined mainly by choice of nursing care delivery models. This study aimed to determine implementation of integrated nursing models toward patient satisfaction in Mitra Medika Amplas Hospital, Medan, North Sumatra.

Subject dan Method: This was a quasi-experiment with two group comparison conducted at Mitra Medika Amplas Hospital, Medan, Indonesia. A sample of 77 patients was selected by consecutive sampling. The data were collected by questionnare and analyzed by t-test.

Result: The results showed that the level of satisfaction in the intervention group stated that 60 people were satisfied ( $78 \%$ ) while the control group stated that 4 people were satisfied (5\%). It was statistically significant $(\mathrm{p}<0,05)$.

Conclusion: The level of patient satisfaction based on the dimensions of tangible quality, empathy, reliability, responsiveness and assurance was higher in the intervention group than in the control group.
\end{abstract}

Keywords: integrated model, patient focused services

\section{Correspondence:}

Deli, Universitas Sumatera Utara Medan. Jl. Dr. T. Mansur No.9, Padang Bulan, Medan, North Sumatra 20222. Email: delitheo.theo@yahoo.com. Mobile: 085361880118

The $7^{\text {th }}$ International Conference on Public Health Solo, Indonesia, November 18-19, 2020|337 https://doi.org/10.26911/the7thicph.04.22 